\title{
SCALE ECONOMIES ESTIMATION IN THE PORK MEAT INDUSTRY IN CHILE
}

\section{Estimación de economías de escala en la industria de la carne de cerdo en Chile}

\author{
Ricardo Marchant S. ${ }^{1 *}$
}

\begin{abstract}
A B S T R A C T
The pork meat industry in Chile exhibits significant rates of production growth, with a decreasing trend in the wholesale market price and growing levels of concentration of the supply in a reduced number of companies. The structural element that sustains concentration and expansion of the production is the presence of increasing returns to scale in the production process. This investigation had the objective to verify the presence of economies of scale in this industry. Using a Cobb-Douglas cost function and the assumption of maximization of the benefits of the company in imperfect competition markets, an econometric model was estimated, that allowed to estimate indirectly the coefficients of the function of underlying production. For the period 1975-2005 the industry presented increasing returns to scale, with an elasticity product-scale of 1.23 and economies of scale, with elasticity cost-production of 0.81 . It was concluded that this industry shows conditions to increase its advantage in costs and to expand its competitiveness in international markets.
\end{abstract}

Key words: return to scale, pork meat industry.

\section{R E S U M E N}

La industria de la carne de cerdo en Chile exhibe tasas significativas de crecimiento de la producción, acompañada por una tendencia decreciente en el precio a nivel de mercado mayorista, y por niveles crecientes de concentración de la oferta en un número reducido de empresas. El elemento estructural que sustenta la concentración y expansión de la producción es la presencia de rendimientos a escala crecientes en el proceso de producción. Esta investigación tuvo por objetivo verificar la presencia de economías de escala en esta industria. Utilizando una función de costos Cobb-Douglas y el supuesto de maximización de beneficios en una empresa en competencia imperfecta, se estimó un modelo econométrico que permitió estimar indirectamente los coeficientes de la función de producción subyacente. Se encontró que para el período 1975-2005, la industria presentó rendimientos a escala crecientes, con una elasticidad producto-escala de 1,23 y economías de escala, con una elasticidad costo-producción de 0,81 . Se concluyó que esta industria presenta condiciones para incrementar su ventaja en costos y expandir su competitividad en los mercados internacionales.

Palabras clave: retorno a escala, industria de la carne de cerdo.

\footnotetext{
${ }^{1}$ Universidad de Chile, Facultad de Ciencias Agronómicas, Casilla 1004, Santiago, Chile. E-mail: ricmarch@uchile.cl

Received: 14 March 2006. Accepted: 7 July 2006.
} 


\section{INTRODUCTION}

The pork meat industry has shown great dynamism in production growth rates as well as growing export volumes (ODEPA, 2004). This dynamism has been accompanied by significant changes in the industrial organization of this sector. In effect, a fundamental element which allowed this growth in the vertical integration front and back, and the concentration of the demand in the corn market, which it is open to foreign markets. The pork meat offer has also been concentrated in a dominant company, revealing important cost advantages for it (Vargas and Foster, 2000; Vargas et al., 2001; Marchant et al., 2003; Marchant, 2006). These trends have caused a decrease in the wholesale market price levels; this trend was also documented for the U.S. market under similar circumstances (Brester and Marsh, 2001). Furthermore, agricultural policy elements function in this sector, linked to the compliance to sanitary regulations for the slaughter as well as the domestic and exterior marketing of pork meat. There are also export quotas towards markets with which Chile has subscribed trade agreements, thus generating important business opportunities for this industry.

One of the theoretical conditions for a market to respond to competition conditions is that the technology present in the industry should show yields at constant rates, both for the factors market as well as for the end product, since the companies will produce their optimum economic level in such quantities as will not have an influence in the balance (Varian, 1992). If a company shows yields in a growing scale of its technology and the perfect information conditions are not present, this company can increase its participation in the market and in this way modify the structure of it, as is argued by Panzar (1989) and Amir (2002). Therefore, the presence of economies of scale in the technological process of a company of the industry generates the conditions for that company to have cost advantages as regards its competition, and eventually consolidate itself as a dominant or leader company in the market. Carried to extremes, scale economy sustains the argument for the existence of a natural monopoly, since in that case the optimum production level coincides with the total demand of the market.

This process can benefit the consumers, in the context of markets functioning with imperfect in- formation, since the price paid is relatively lower, reflecting the greater efficiency of the company that shows economies of scale in its technological processes, as regards that which would prevail in a competitive market.

The identification and econometric estimation of economies of scale has been done using a translogarithmic costs function over panel data, linking size of the plant and variables related to technology, which emphasis on the cost elasticity at the level of primary production, such as happens in MacDonald and Ollinger (2000) and Ollinger et al. (2005). This functional form is flexible and, under determined restrictions on its coefficients, can represent several functional forms and can be applied to multi-product enterprises. Ogunyinka and Featherstone (2003) arrive at this same conclusion after estimating a generalized Box-Cox production cost model, applied to agricultural products and raw materials in the United States. On the other hand, Coffey and Featherstone (2004) employ non-parametric techniques to estimate scale economies with crossed section data, fundamentally because it is not necessary to restrict the technology employed to a specific functional form.

The objectives of this research were: (a) characterize the nature of the pork meat production process, as regards scale yields and identify the type of economy of scale present in the industry and, (b) simulate the behavior of the median cost for specific production levels.

\section{MATERIALS AND METHODS}

In this research the estimated model is based in a time series, is of aggregate character and takes into account the fact that the industry is highly concentrated. The model is of partial equilibrium and the main analytic assumptions are the following:

The technology of the industrial sector of pork meat production, by hypothesis, can be structured according to the Cobb-Douglas technology (Varian, 1992), that is: considering a multiplicative relationship between the factors, with substitution to a decreasing rate between them. Therefore:

$Y(K, L)=\beta_{0} L^{\beta_{1}} K^{\beta_{2}}$

Where $Y$ represents pork meat production, $L$ the amount of the labor factor, $K$ the amount of the 
capital factor and $\beta_{0}, \beta_{1}$ y $\beta_{2}$ are the relationship coefficients.

Starting from this expression and considering a long term situation, a technology shows yields in a growing scale when the sum of the exponents accompanying the variables labor and capital is greater than one, so that said technology shows economies of scale. In this context, the average production cost decreases while the production level increases, up to a certain limit.

An indirect way of estimating the coefficients of function (1) is by the estimation of the costs function obtained from the Cobb-Douglas technology, more specifically, by means of the marginal costs function, since this is expressed in terms of the price of the factors and the level of the production. This is the fundament to set out the following assumptions.

Maximization of benefits in imperfect competition. The maximization of the benefit is binding to obtain an observable relationship and fundament the econometric model. The optimum condition of an (representative) enterprise which determines its production level at the level at which the market price (Py) equals the marginal cost. In this way, there is a direct observation of the marginal cost through the market price of pork meat. Thus, we see that the total cost function, issuing from a CobbDouglas technology, can be expressed as:

$C(w, r, Y)=M w^{\frac{\beta_{1}}{\beta_{1}+\beta_{2}}} r^{\frac{\beta_{2}}{\beta_{1}+\beta_{2}}} Y^{\frac{1}{\beta_{1}+\beta_{2}}}$

where $\mathrm{C}$ is the total cost level, $\mathrm{w}$ the salary level, $\mathrm{r}$ is the interest rate of placements, $\mathrm{Y}$ is the pork production level, and the factor $\mathrm{M}$ is a constant equal to $\beta_{0}^{\frac{-1}{\beta_{1}+\beta_{2}}}\left[\left(\frac{\beta_{1}}{\beta_{2}}\right)^{\frac{\beta_{2}}{\beta_{1+}+\beta_{2}}}+\left(\frac{\beta_{1}}{\beta_{2}}\right)^{\frac{-\beta_{1}}{\beta_{1}+\beta_{2}}}\right]$. market price of pork meat (Py) is equal to the marginal cost $(C M g)$, a condition of the first order for the maximization of the benefit.

$C M g=\frac{\partial C}{\partial Y}=\frac{1}{\beta_{1}+\beta_{2}} M w^{\frac{\beta_{1}}{\beta_{1}+\beta_{2}}} r^{\frac{\beta_{2}}{\beta_{1}+\beta_{2}}} Y^{\frac{1-\left(\beta_{1}+\beta_{2}\right)}{\beta_{1}+\beta_{2}}}$

We consider the optimum condition for the case of a highly concentrated market in the market of the final product (pork meat). In this case, the price is weighted by a factor which measures the power of monopoly of the representative enterprise, whose estimation is found in the pioneer work of Bresnahan (1982). This factor alters the median price level to be observed in the industry, but not the estimation of the exponents of the function.

$P y=\left[\frac{1}{1-\varepsilon_{d p y}}\right]=\frac{1}{\beta_{1}+\beta_{2}} M w^{\frac{\beta_{1}}{\beta_{1}+\beta_{2}}} r^{\frac{\beta_{2}}{\beta_{1}+\beta_{2}}} Y^{\frac{1-\left(\beta_{1}+\beta_{2}\right)}{\beta_{1}+\beta_{2}}}$

In the present work, the interest is centered in the exponent accompanying the production level, as it reflects the type of yield to scale present in the pork meat production process. In this sense, it is fundamental to know the sign of this exponent.

\section{Econometric model to be estimated}

In order to simplify notation, expression (4) can be re-parameterized, substituting the monopoly power factor $\left(1-\frac{1}{\varepsilon_{d p y}}\right)$, by $\mathrm{k}$; the constant $\left(\frac{1}{\beta_{1}+\beta_{2}}\right) M$, by $\alpha_{0}$; the exponent accompanying the salary variable $(\mathrm{w})$, $\frac{\beta_{1}}{\beta_{1}+\beta_{2}}$ by variable $\alpha_{1}$; the exponent accompanying the variable interest rate (r), $\frac{\beta_{2}}{\beta_{1}+\beta_{2}}$, by variable $\alpha_{2}$; and the exponent which accompanies the pork meat production level, $\frac{1}{\beta_{1}+\beta_{2}}$ by variable $\alpha_{3}$, thus obtaining:

$P y k=\alpha_{0} w^{\alpha_{1}} r^{\alpha_{2}} Y^{\alpha_{3}}$

$P y=\frac{\alpha_{0} w^{\alpha_{1} r^{\alpha_{2}} Y \alpha_{3}}}{k}$

Applying logarithm to (6), we obtain:

$\operatorname{LnPy}=\operatorname{Ln} \alpha_{0}-\operatorname{Lnk}+\alpha_{1} \operatorname{Ln} w+\alpha_{2} \operatorname{Ln} r+\alpha_{3} \operatorname{Ln} Y$

Then, the model to be estimated can be specified as:

$L n P y=\phi_{0}+\phi_{1} L n w+\phi_{2} L n r+\phi_{3} L n Y+\varepsilon_{t}$

In model (8), $\phi_{0}=\operatorname{Ln} \alpha_{0}-\operatorname{Lnk}$, while coefficient $\phi_{3}$ represents the expression $\frac{1-\left(\beta_{1}+\beta_{2}\right)}{\beta_{1}+\beta_{2}}$, which is the exponent of pork meat production level. If this coefficient is negative, it suggests that the technology shows yields on a growing scale, since $\beta_{1}+\beta_{2}>1$. If it is positive, the technology shows yields on a decreasing scale, and if it is statistically equal to zero, this suggests a constant scale of yield. The error is assumed as white noise. 
Before the estimation was done, the variables were characterized from the statistical point of view and the hypothesis of normality of the same was assessed by means of the Jarque-Bera statistics (Pindyck and Rubinfeld, 2001).

The definition of the variables observed for the period 1975-2005 was: Py, wholesale price of pork meat expressed in Chilean pesos per kilogram; w, salary index of the Chilean economy for the industrial sector, analysis unit of this research; $r$, interest rate of the financial system for one-year placements ; Y, port meat production level, measured in tons. The data were obtained from ODEPA (2005) service of the Ministry of Agriculture; from the Central Bank of Chile (2005) and from the National Statistics Institute (INE, 2005).

The statistical description of the series employed is shown in Table 1.

\section{RESULTS AND DISCUSSION}

\section{Unit root test for the variables of the model}

Given the characteristics of the estimated model, the variables were incorporated in their logarithm transformation. The unit root test was applied in this manner. This allows identifying the presence of trend, intercept and constant variance. In this last case, the series has constant variance when, in absolute terms, the statistic of Dickey-Fuller Augmented (DFA) (Johnston and Dinardo, 2001) calculated is higher than that tabulated. The result is shown in Table 2. It can be pointed out that all variables were stationary in the first differentiation, except for production, which was so in the second.

\section{Estimation of the econometric model}

The estimated model considered controlling the autocorrelation of the residues and the presence of unit root in the variables considered. In this sense it

Table 1. Pork meat industry. Statistical characteristics of the series employed. Period 1975-2005. Chile.

Cuadro 1. Industria de la carne de cerdo. Caracterización estadística de las series utilizadas. Período 1975 -2005. Chile.

\begin{tabular}{lcccc}
\hline & \multicolumn{4}{c}{ Variables } \\
\cline { 2 - 5 } & $\begin{array}{c}\text { Pork price } \\
(\mathbf{\$ ~ k g} \mathbf{~})\end{array}$ & $\begin{array}{c}\text { Production } \\
\mathbf{( t )}\end{array}$ & $\begin{array}{c}\text { Salary index } \\
\text { industrial sector. } \\
\text { Basis } \mathbf{~ 1 9 9 3}\end{array}$ & $\begin{array}{c}\text { Real interest rate } \\
\text { placements } \mathbf{1} \text { to 3 } \\
\text { years, yearly average }\end{array}$ \\
\hline Average & 1104 & 149826 & 208.2 & 24.5 \\
Minimum & 772 & 24880 & 86.0 & 4.0 \\
Maximum & 1484 & 405000 & 261.6 & 176.0 \\
Standard Dev. & 201 & 112427 & 47.6 & 34.7 \\
Variation Coeff., \% & 18.2 & 75.0 & 22.8 & 141.6 \\
Statistic for a normality & 0.97 & 3.81 & 3.25 & 181.0 \\
Hypothesis Jarque-Bera & $(0.61)$ & $(0.14)$ & $(0.19)$ & $(0.00)$ \\
\hline
\end{tabular}

Source: Prepared on the basis of statistics from ODEPA (2004), Central Bank (2005) and INE (2005).

$1 \mathrm{US} \$=\$ 559.7$ Chilean pesos

Table 2. Unit root test results in the model variables.

Cuadro 2. Resultados de la prueba de raíz unitaria en las variables del modelo.

\begin{tabular}{lcccc}
\hline Variable & $\begin{array}{c}\text { Integration } \\
\text { order }\end{array}$ & $\begin{array}{c}\text { Dickey-Fuller } \\
\text { Augmented } \\
\text { (DFA) statistic }\end{array}$ & $\begin{array}{c}\text { Critical value } \\
\text { DFA at 1\% }\end{array}$ & $\begin{array}{c}\text { Presence of } \\
\text { significant } \\
\text { intercept and } \\
\text { trend }\end{array}$ \\
\hline Log pork meat price & $\mathrm{I}(1)$ & -4.58 & -4.32 & No \\
Log salaries & $\mathrm{I}(1)$ & -6.72 & -4.32 & No \\
Log interest rate & $\mathrm{I}(1)$ & -6.37 & -4.32 & No \\
Log pork meat production & $\mathrm{I}(2)$ & -8.18 & -4.32 & No \\
\hline
\end{tabular}


was justified to incorporate the variables in logarithms; the salaries variable in the first difference and the correction factor of the autocorrelation of the residues AR(1) appearing in model (8). To this end the model was estimated with the CochraneOrcut correction (Johnston y Dinardo, 2001), to attenuate the effect of the autocorrelation in the residues of the model. The AR(1) factor allows the introduction into the model of the systematic part which links the residues in $\mathrm{t}$ and $\mathrm{t}-1$, generating a new residual term which complies with the assumptions of the classic model. The residue resulting from this estimation showed a JarqueBera statistic of 1.55 , a level below 5.99, critical value of the $\mathrm{X}^{2}$ distribution for 2 degrees of freedom, therefore is accepted the null hypothesis that the residues follow a normal distribution, and therefore there is no evidence of bad specification of the proposed model.

On the other hand, the residues of the estimated model did not present a unit root at 5\% significance according to the Dickey-Fuller test, since the resultant value was of -4.17 , and the critical value -3.57 . This result suggests that the variables of the model co-integrate, that is to say, there is a long term balance relationship among them.

Individual coefficients differed from zero, according to statistic $t$, as well as the group of the same, as seen in statistic F.

The coefficient accompanying production resulted different and below zero, this suggests that the pork meat production process shows yields on a decreasing scale. This is important in terms of competitiveness of the sector, as the mean costs follow a decreasing trajectory in the measure that production level increases.

According to the estimated model, the addition of the elasticity product-labor and product-capital reached 1.298; this means that if the use of the labor and capital factors increases by $1 \%$, production rises by $1.298 \%$. This shows that the industry shows yields on a growing scale. Analyzing algebraically according to expression (2) in individual terms, the product-labor elasticity resulted as 0.87 and that of product-capital was 0.36 . To fundament these results, a contrast was effected upon a linear combination of the estimated coefficients, to validate that the sum of the interest rate coefficient (-0.089) and of the salaries (0.71), are equal to 1 , given the definition of coefficients $\alpha_{1}$ and $\alpha_{2}$ of equation (7) being accepted the null hypothesis. To this end, a t test is applied, allowing to prove $H_{0}: \phi_{1}$ $+\phi_{j}=c$. Therefore the estimated $\mathrm{t}$ corresponds to, $\sqrt{\frac{\left(\phi_{1}+\phi_{j}\right)-c}{\operatorname{Var}\left(\phi_{\mathrm{i}}\right)+\operatorname{Var}\left(\phi_{\mathrm{j}}\right)+2 \operatorname{Cov}\left(\phi_{\mathrm{i}}, \phi_{\mathrm{j}}\right)}}$, which is contrasted with $\mathrm{t}$ of the table. This test indicates that when the prices of the factors rise by $1 \%$, the mean price of the industry also rises by $1 \%$.

These results suggest that the utilization of the factors in the industry is found in the rational steps, according to the theory of production, that is, the concave zone of the production function, where the benefit of the enterprise is positive. The case presented is characterized because the elasticity of the product factor is less than 1 and above zero (Varian, 1992). On the other hand, given the productfactor elasticity found, it can be stated that the process (aggregated) is more capital-intensive.

Given the above results, the industry presents economies of scale, since the variation of the costs as regards production is estimated as 0.81 (this is the reciprocal result of the sum of the productfactor elasticity). This implies that when production (or the scale) rises by $1 \%$, the total production cost rises by $0.81 \%$, therefore the average cost diminishes. This amount is comparable to that reported by MacDonald and Ollinger (2000), and in the case of the United States was of 0.92; another study for the same market reported 0.98 (Ollinger et al., 2005).

The real process sustaining the behavior of the port meat industry is its deep technological transformation, supported by the behavior of decreasing corn prices, a most important supply for pig feeding; this has taken place mainly since 1991. In this sense, it can be affirmed that the cost reduction associated to the behavior of the corn prices, has been a circumstance contributing to the processing industry to present economies of scale. This fact is also reported for the case of the pork meat market in the United States (Morrison, 1999). An additional incentive for the expansion of production is constituted by the opening of foreign markets by mean of trade agreements, as well as the restrictions to the import of beef meat due to animal health problems in some supplier countries. 
Simulation of the behavior of the average production cost of pork meat

Given the results of the estimation (Table 3) a model was configured to try to simulate the long term behavior of the average cost of production of pork meat, to discuss aspects related to the competitiveness of the industry. This is how that, considering equation (2), the estimation of the coefficients and a hypothesis about the value of the parameter $\mathrm{M}$, the following equation for the added cost for the pork meat industry was obtained:

$$
C=M w^{0,7} r^{0,23} Y^{0,81}
$$

Assuming as numerals (equal to 1 ) for component $\mathrm{M}$, and the price of the factors $\mathrm{w}$ and $\mathrm{r}$, the average cost is estimated $(\mathrm{C} / \mathrm{Y})$ for different production levels, adjusting the level to the order of magnitude of the market prices. The result is shown in Figure 1. It can

Table 3. Pork meat industry. Estimated model result for period 1975-2005. Chile.

Cuadro 3. Industria de la carne de cerdo. Resultado de la estimación del modelo para el período 1975-2005. Chile.

\begin{tabular}{|c|c|c|c|c|}
\hline Variables & Coefficient & Standard error & Statistic $\mathbf{t}$ & Probability \\
\hline \multicolumn{5}{|c|}{$\begin{array}{l}\text { Dependent variable: Log pork meat } \\
\text { price }\end{array}$} \\
\hline Constant & 9.914 & 0.5928 & 16.724 & 0.000 \\
\hline Log interest rate & -0.0895 & 0.0361 & -2.479 & 0.020 \\
\hline$\Delta$ Log salaries & 0.7198 & 0.2552 & 2.819 & 0.0095 \\
\hline Log pork meat production & -0.2322 & 0.0462 & -5.0227 & 0.0000 \\
\hline $\operatorname{AR}(1)$ & 0.577 & 0.1884 & 3.0629 & 0.0053 \\
\hline $\mathrm{R}^{2}$ & 0.88 & & & \\
\hline $\mathrm{R}^{2}$ adjusted & 0.86 & & & \\
\hline Durbin-Watson & 1.633 & & & \\
\hline $\mathrm{F}$ & 47.306 & & & \\
\hline Probability F & 0.000 & & & \\
\hline
\end{tabular}

$\mathrm{AR}(1)$ : Cochrane-Orcut correction for the first order correlation of the residues; $\mathrm{R}^{2}$, multiple determination coefficient to measure the adjustment fitness of the model; F statistic applied to asses the global significance of the model; Durbin-Watson, statistic applied to evaluate the presence of autocorrelation in the residues of the model.

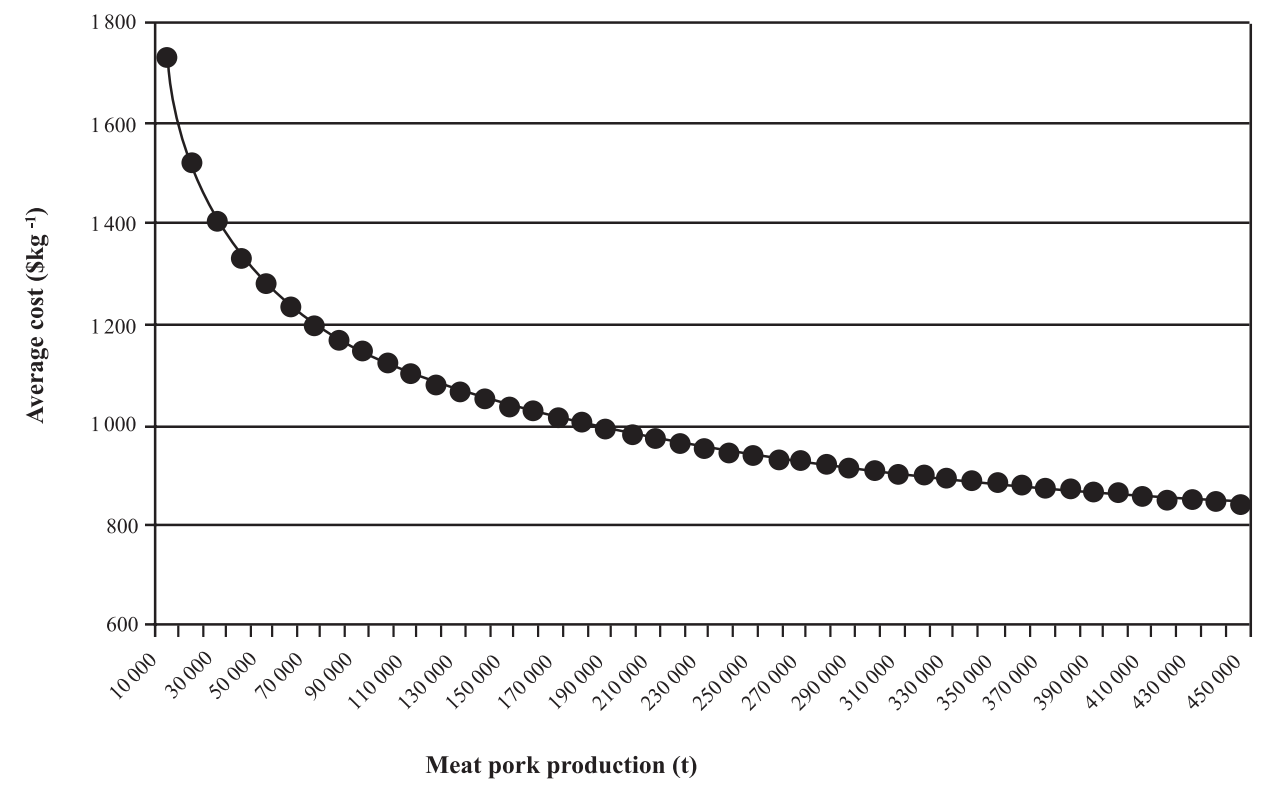

Figure 1. Simulated average cost and meat pork production of the industry. Chile.

Figura 1. Costo medio simulado y producción de carne de cerdo de la industria. Chile. 
be seen that the long term average cost places itself around $\$ 800 \mathrm{~kg}^{-1}$, as the production level of the industry rises. If the simulation describes reasonably the trajectory of the mean production cost, it can be affirmed that the industry could face a long term price of equilibrium around $\$ 800 \mathrm{~kg}^{-1}$.

\section{CONCLUSIONS}

1) Between 1975 and 2005 the Chilean pork meat industry showed increasing yields to scale, under the supposition of the technology prevailing in the industry can be described by a Cobb-Douglas function, and the companies maximize benefits. The product-scale elasticity was estimated as 1.298.

2) Between 1975 and 2005, the pork meat industry showed economies of scale, given the cost-produc- tion elasticity of 0.81 , the estimation revealed that the factors are being used in optimal amounts, according to the theory of production and that the process is more intensive in the use of capital as compared to the labor factor.

3) In a simulation of the behavior of the average cost in the pork meat industry, in a scenario of increasing production levels, this converges around a level of $\$ 800 \mathrm{~kg}^{-1}$.

4) The pork meat industry presents conditions to continue lowering its production costs, as compared to the industry in the United States, thus generating the condition to increase its competitiveness in the international market of this product.

\section{LITERATURE CITED}

Amir, R. 2002. Market structure, scale economies and industry performance. 40 p. Discussion paper $\mathrm{N}^{\circ} 00$ 08. University of Copenhagen, Institute of Economics, Copenhagen, Denmark. On line. Available in: http://www.econpapers.repec.org Accessed October $15,2005$.

Banco Central de Chile. 2005. Estadísticas macroeconómicas de Chile. En línea. Disponible en http:// www.bcentral.cl Leído 17 de diciembre de 2005.

Bresnahan, T. 1982. The oligopoly solution concept is identified. Economics Letter 10:87-92.

Brester, G., and J. Marsh. 2001. The effects of U.S. meat packing and livestock production technologies on marketing margins and prices. J. Agric. Resour. Econ. 26:445-462.

Coffey, B., and A. Featherstone. 2004. Nonparametric estimation of multiproduct and product-specific economies of scale. Selected paper Southern Agricultural Economics Association (SAEA). $36^{\circ}$ Annual Meeting, Tulsa, Oklahoma, USA, February 14-18. On line. Available in: http://agecon. lib.umn.edu/cgi-bin/pdf_view.p1?paperid= 12428\&ftype $=$.pdf Accessed December 20, 2005.

INE. 2005. Anuario de estadísticas agropecuarias. 20042005. 132 p. Instituto Nacional de Estadísticas, Santiago, Chile.

Johnston J., y J. Dinardo. 2001. Métodos de econometría. 590 p. Ed. Vicens-Vives, Madrid, España.

MacDonald, J., and M. Ollinger. 2000. Scale economies and consolidation in hog slaughter. Am. J. Agric. Econ. 82:334-346.
Marchant, R. 2006. Equilibrio de un oligopolio con empresa dominante: una aplicación al mercado de la carne de cerdo en Chile. Revista Economía Agraria $\mathrm{N}^{\circ} 10$ p. 63-72.

Marchant, R., W. Foster, y J. Ortega. 2003. Modelo de duopolio de Cournot: caso del maíz en Chile. p 275288. $8^{\circ}$ Congreso de Economía Agraria, Santiago, Chile. 27 a 29 de octubre. Pontificia Universidad Católica de Chile, Santiago, Chile.

Morrison, C. 1999. Cost economies and market power: the case of the U.S. meat packing industry. $31 \mathrm{p}$. University of California, Department of Agricultural and Resources Economics, Davis, California, USA.

ODEPA. 2004. Mercado de la carne de cerdo. Oficina de Estudios y Políticas Agrarias (ODEPA). Disponible en http://www.odepa.gob.cl Leído el 15 de diciembre de 2005.

Ogunyinka, E., and A. Featherstone. 2003. On the choice of functional forms in the measurement of scale and scope economies: generalized Box-Cox and composite cost function. Selected paper for presentation at the Southern Agricultural Economics Association Annual Meeting (SAEA), Mobile, Alabama. February 1-5, 2003. Available in http:// agecon.lib.umn.edu/cgi-bin/pdf_view.pl?paperid= 6759\& ftype=.pdf Accessed November 20, 2005.

Ollinger, M., J. MacDonald, and M. Madison. 2005. Technological change and economies of scale in U.S. poultry processing. Am. J. Agric. Econ. 87:116-129. 
Panzar, J. 1989. Technological determinants of firm and industry structure. Vol. 1 p. 3-59. In Schmalensee, R. and R. Willing (eds.). Handbook of industrial organization. Elsevier, Amsterdam, Holanda.

Pindyck, R. and D. Rubinfeld. 2001. Econometría: modelos y pronósticos. 661 p. $4^{\mathrm{a}}$ ed. Mc Graw Hill, México.

Vargas, G., y W. Foster. 2000. Concentración y coordinación vertical en la agricultura chilena. 9 p. Taller Concentración de los segmentos de transformación y mercadeo del sistema agroalimentario y sus efectos sobre los pobres rurales. Santiago. 27 y 28 de noviembre. Pontificia Universidad Católica de Chile, Depto. Economía Agraria, Santiago, Chile.
Vargas, G., M. Raddatz, y W. Foster. 2001. Convergencia en la organización de la industria de aves y cerdos: comparación de Chile y Estados Unidos. p. 103-112. $6^{\circ}$ Congreso de Economía Agraria, Santiago. 27 a 29 de noviembre. Universidad de Chile, Facultad de Ciencias Agronómicas, Santiago, Chile.

Varian, H. 1992. Análisis microeconómico. 656 p. $3^{\mathrm{a}}$ ed. Antoni Bosch, Barcelona, España. 